\title{
IMMUNIZATION AGAINST BRUCELLA INFECTION ${ }^{1}$
}

\author{
II. Effectiveness of a Streptomycin-Dependent Strain of Brucella melitensis \\ MENDEL HERZBERG, SANFORD S. ELBERG, AND KARL F. MEYER \\ Department of Bacteriology, University of California, Berkeley, California, and the George Williams \\ Hooper Foundation, University of California, San Francisco, California
}

Received for publication June 3, 1953

In previous reports (Elberg and Herzberg, 1953; Herzberg and Elberg, 1953) the isolation and characteristics of a streptomycin-dependent mutant of Brucella melitensis were described.2 The streptomycin-dependent strain retained the biochemical and antigenic characteristics of the virulent parent strain but differed in a requirement for streptomycin for its growth. Growth in vivo was not influenced detectably by in vivo administration of streptomycin.

The following studies describe the capabilities of this strain for inducing protection of mice and guinea pigs against experimental infection with virulent $B$. melitensis.

\section{MATERIALS AND METHODS}

These were described in considerable detail in the first paper of the series (Herzberg and Elberg, 1953) and need not be restated here. Suffice it to say at this point that protection was assessed in terms of the ability of the animal to sterilize spleen tissue of the organisms constituting the "challenge".

\section{EXPERIMENTAL RESULTS}

The first sets of observations deal with mice which had received one injection of streptomycindependent strain of $B$. melitensis.

Mice were inoculated subcutaneously with doses ranging from $10^{6}$ to $10^{8}$ organisms, both large and small colony forms being employed. After a rest period of 5 weeks, the immunities were tested against graded challenge doses. Three

1 This investigation was supported in part by a grant E22 (C5) from the Division of Research, Grants, and Fellowships, U. S. Public Health Service.

2 While this paper was in preparation, Olitzki and Szenberg (1953) reported data on Brucella abortus, strain 19, which confirm that reported earlier (Elberg and Herzberg, 1953) and in this manuscript relative to virulence and antigenicity. weeks after the challenge infection the animals were sacrificed and spleen homogenates were cultured in triplicate. ${ }^{3}$

The results which are presented in table 1 indicate that significant protection, with small probabilities of the differences between control and test animals occurring by chance, was achieved in only two groups. These animals had received the lightest challenge dose and had been given the largest immunizing dose of vaccine. The challenge dose was approximately equal to one $\mathrm{ID}_{s 0}{ }^{4}$ as shown by the rate of infection in the control series. No significant protection was demonstrable in any other group when the differences were tested by the chi square method. No difference in protective ability was shown between the small and large colony variants of the streptomycin-dependent strain.

Since little protection had been conferred by one injection of vaccine in the previous experiment, two doses of vaccine prepared from the small colony variant were administered to mice subcutaneously. Three weeks elapsed between the two immunizing inoculations. Four weeks later the protection was tested against two challenge doses and the animals were examined three weeks after the challenge infection had been given. As shown in table 2, significant protection was obtained in all cases except one (group G) as tested by the chi square method, indicating the extremely low probability that the difference between test and control could have

\footnotetext{
In all cases, in this and in subsequent experiments with streptomycin-dependent vaccine, cultures of spleen homogenates also were plated in duplicate on streptomycin containing agar (500 $\mu \mathrm{g}$ streptomycin per $\mathrm{ml}$ ). In no case were vaccine organisms isolated at necropsy.

- An ID $_{50}$ is defined in this work as the minimal number of cells required on subcutaneous injection to produce after 3 to 4 weeks an infection in 50 per cent of the animals.
} 
occurred by chance. Protective rates as high as 93 per cent and 78 per cent were achieved (groups A and B) against challenges which infected 94 to 100 per cent of the control animals. These challenge doses were approximately 20 and $200 \mathrm{ID}_{50}$. This high degree of immunity was induced by the largest dose of vaccine $\left(10^{10}\right.$ cells $)$, and correspondingly smaller degrees of immunity were induced in animals receiving smaller doses of vaccine.

An analysis of the results of varying the dose of vaccine revealed that in those groups receiving vised to test the effect of drug administration upon the resulting immune state.

A single dose of $10^{10}$ streptomycin-dependent cells of the small colony mutant was administered subcutaneously, and various schedules of streptomycin administration were followed for each group. Two control groups were included, one of which received only the vaccine whereas the other received neither vaccine nor drug. Four weeks after vaccine administration all groups were challenged, and four weeks later the animals were sacrificed. In table 3 the data make it

TABLE 1

Response of mice immunized with living streptomycin-dependent mutant to subsequent challenge with a virulent strain of Brucella melitensis

\begin{tabular}{|c|c|c|c|c|c|c|c|c|}
\hline \multirow{2}{*}{ GROUP } & \multirow{2}{*}{$\begin{array}{c}\text { MMUONIZING } \\
\text { INFECTION DOSE }\end{array}$} & \multirow{2}{*}{$\begin{array}{l}\text { CHALLEENGE } \\
\text { INFECTION DOSE }\end{array}$} & \multicolumn{2}{|c|}{ TEST ANTMALS } & \multicolumn{2}{|c|}{ CONTROL ANMALS } & \multirow{2}{*}{$\mathrm{CHI}^{2}$} & \multirow{2}{*}{$\mathbf{P}$} \\
\hline & & & $\begin{array}{c}\text { Infected/ } \\
\text { total }\end{array}$ & $\begin{array}{l}\text { Per cent } \\
\text { infected }\end{array}$ & $\begin{array}{c}\text { Infected/ } \\
\text { total }\end{array}$ & $\begin{array}{l}\text { Per cent } \\
\text { infected }\end{array}$ & & \\
\hline $\mathbf{A}$ & $1.7 \times 10^{8}$ & $4.1 \times 10^{7}$ & $13 / 15$ & 86.6 & $9 / 10$ & 90 & 0.14 & $0.7-0.5$ \\
\hline B & small colony & $4.1 \times 10^{5}$ & $6 / 14$ & 42.9 & $7 / 10$ & 70 & 0.81 & $0.5-0.3$ \\
\hline $\mathbf{C}$ & form & $4.1 \times 10^{3}$ & $1 / 15$ & 6.6 & $5 / 10$ & 50 & 4.03 & $0.05-0.02$ \\
\hline D & $9.7 \times 10^{6}$ & $3.5 \times 10^{7}$ & $14 / 15$ & 93.3 & $7 / 7$ & 100 & 0.12 & $0.8-0.7$ \\
\hline $\mathbf{E}$ & small colony & $3.5 \times 10^{5}$ & $8 / 16$ & 50.0 & $5 / 7$ & 71 & 0.24 & $0.7-0.5$ \\
\hline $\mathbf{F}$ & form & $3.5 \times 10^{3}$ & $6 / 14$ & 42.8 & $3 / 6$ & 50 & 0.53 & $0.5-0.3$ \\
\hline $\mathbf{G}$ & $1.9 \times 10^{8}$ & $4.1 \times 10^{7}$ & $13 / 15$ & 86.6 & $9 / 10$ & 90 & 0.68 & $0.5-0.3$ \\
\hline $\mathbf{H}$ & large colony & $4.1 \times 10^{6}$ & $10 / 15$ & 66.6 & $7 / 10$ & 70 & 0.02 & $0.9-0.8$ \\
\hline I & form & $4.1 \times 10^{3}$ & $0 / 15$ & 0 & $5 / 10$ & 50 & 4.50 & $0.05-0.02$ \\
\hline $\mathbf{J}$ & $6.0 \times 10^{5}$ & $3.5 \times 10^{7}$ & $12 / 14$ & 85.6 & $7 / 7$ & 100 & 0.06 & $0.9-0.8$ \\
\hline $\mathbf{K}$ & large colony & $3.5 \times 10^{5}$ & $10 / 15$ & 66.6 & $5 / 7$ & 71 & 0.07 & $0.8-0.7$ \\
\hline L & form & $3.5 \times 10^{3}$ & $7 / 14$ & 50.0 & $3 / 6$ & 50 & 0 & 1.0 \\
\hline
\end{tabular}

A 5 week period elapsed between immunization and challenge by strain MM472 of Brucella melitensis and a 3 week period elapsed between challenge and sacrifice.

the smaller challenge dose (groups $\mathrm{A}, \mathrm{D}, \mathrm{G}, \mathrm{J}$, $\mathrm{M})$ the chi square value was 19.197 , where $n$ is 4 , and $P$ is equal to less than 0.01 . For groups receiving the higher challenge (groups $\mathrm{B}, \mathrm{E}, \mathrm{H}$, $K)$, chi square was 7.79 , where $n$ is 3 , and $P$ is equal to less than 0.01 . These values indicate that variation in the dose of vaccine did have an effect on protection since the results could not have been due to chance.

In the experiments reported previously (Herzberg and Elberg, 1953) it was shown conclusively that administration of streptomycin to the host had no perceptible influence on the growth or persistence of the streptomycin-dependent $\mathrm{mu}$ tant in vivo. The following experiment was de- evident that all groups had been protected significantly as compared with their controls (groups 153 and 154). However, the analysis of all immunized groups, including those which had received no postvaccinal streptomycin therapy, established the fact that any difference between groups could have arisen by chance. That is, the chi square value for groups receiving the smaller challenge (odd numbered groups 141 to 151) was 5.472 , where $n$ equals 5 and $P$ equals 0.5 to 0.3 . The chi square value for those groups receiving the larger challenge (even numbered groups 142 to 152 ) was 4.935 , where $n$ equals 5 and $P$ equals 0.5 to 0.3 . Thus, the administration, or lack of administration, of the drug had no 
measurable effect on the immunity produced against two doses of virulent cells although in all cases the immunity so produced was significant. One inoculation of $10^{10}$ streptomycindependent cells was sufficient to protect 77.8 and 72.3 per cent of animals receiving challenges which infected 70 and 90 per cent of the control animals. Such protection was not as high as that mentioned groups. No protection was found in any other group when tested against larger doses of virulent cells. Thus, the guinea pig was not immunized as easily as the mouse.

\section{DIscussion}

It has generally been accepted that active immunization against brucellosis requires stimula-

TABLE 2

Response of mice immunized with two inoculations of the streptomycin-dependent mutant

\begin{tabular}{|c|c|c|c|c|c|c|}
\hline GROUP & norONIZING INFTCTION DOSE & $\begin{array}{c}\text { CBALLENGE INYECtion } \\
\text { DOSE }\end{array}$ & InTxCTXD/тоTAL & $\begin{array}{l}\text { PRR CENT } \\
\text { INYECTED }\end{array}$ & $\mathrm{CHI}^{2}$ & $\mathbf{P}$ \\
\hline $\mathbf{A}$ & $\begin{array}{l}1 \mathrm{st}-1.7 \times 10^{10} \\
2 \mathrm{nd}-4.1 \times 10^{10}\end{array}$ & $8.0 \times 10^{4}$ & $1 / 14$ & 7 & 20.8 & 0.01 \\
\hline B & $\begin{array}{l}1 \mathrm{st}-1.7 \times 10^{10} \\
2 \mathrm{nd}-4.1 \times 10^{10}\end{array}$ & $8.0 \times 10^{5}$ & $3 / 14$ & 21 & 17.2 & 0.01 \\
\hline D & $\begin{array}{l}1 \mathrm{st}-1.7 \times 10^{\circ} \\
2 \mathrm{nd}-4.1 \times 10^{\circ}\end{array}$ & $8.0 \times 10^{4}$ & $4 / 15$ & 27 & 13.4 & 0.01 \\
\hline $\mathbf{E}$ & $\begin{array}{l}1 \mathrm{st}-1.7 \times 10^{\circ} \\
2 \mathrm{nd}-4.1 \times 10^{\circ}\end{array}$ & $8.0 \times 10^{5}$ & $10 / 14$ & 71 & 10.7 & 0.01 \\
\hline $\mathbf{G}$ & $\begin{array}{l}1 \mathrm{st}-1.7 \times 10^{8} \\
2 \mathrm{nd}-4.1 \times 10^{8}\end{array}$ & $8.0 \times 10^{4}$ & $8 / 11$ & 71 & 1.19 & $0.3-0.2$ \\
\hline H & $\begin{array}{l}1 \mathrm{st}-1.7 \times 10^{8} \\
2 \mathrm{nd}-4.1 \times 10^{8}\end{array}$ & $8.0 \times 10^{5}$ & $9 / 14$ & 64 & 4.84 & $0.05-0.02$ \\
\hline $\mathbf{J}$ & $\begin{array}{l}1 \mathrm{st}-1.7 \times 10^{7} \\
2 \mathrm{nd}-4.1 \times 10^{7}\end{array}$ & $8.0 \times 10^{4}$ & $6 / 15$ & 40 & 9.05 & 0.01 \\
\hline $\mathbf{K}$ & $\begin{array}{l}1 \mathrm{st}-1.7 \times 10^{7} \\
2 \mathrm{nd}-4.1 \times 10^{7}\end{array}$ & $8.0 \times 10^{6}$ & $8 / 13$ & 61 & 5.32 & $0.05-0.02$ \\
\hline $\mathrm{N}$ & None & $8.0 \times 10^{4}$ & $17 / 18$ & 94 & - & - \\
\hline 0 & None & $8.0 \times 10^{8}$ & $17 / 17$ & 100 & - & - \\
\hline
\end{tabular}

Three weeks between immunizing inoculations.

Challenged 4 weeks after last immunizing dose with strain MM472.

Sacrificed 3 weeks after challenge.

resulting from two inoculations but was significant, however.

When attention was directed to the guinea pig, it was observed that an entirely different situation existed, for barely significant protection was achieved after 3 inoculations (table 4). One inoculation of vaccine when tested against a challenge dose infective for 80 per cent of the control animals appeared more effective than two inoculations against a challenge which was approximately twice that administered to the above tion of the immune mechanisms of the host over a relatively protracted time. Such a situation has been achieved by (1) twice-daily inoculation of a soluble antigen for 14 days (Elberg, 1952), (2) less frequent administration of a soluble antigen in adjuvants (Live, 1949), and (3) by the growth and persistence of a living avirulent organism in the cells and fluids of the host, as practised currently in control of the natural disease in cattle.

Since no data in brucella investigations existed 
TABLE 3

Effect of streptomycin administration to mice upon their active immunization against Brucella melitensis infection

\begin{tabular}{|c|c|c|c|c|c|c|}
\hline GROOP & $\begin{array}{l}\text { POSTVACCINAL ADYINISTRATION } \\
\text { OF DRUG }\end{array}$ & CBALLINOI DOSE & $\begin{array}{l}\text { INESCTED/ } \\
\text { TOTAL }\end{array}$ & $\begin{array}{l}\text { PER CENT } \\
\text { INTRCTISD }\end{array}$ & $\mathrm{CHI}^{2}$ & $\mathbf{P}$ \\
\hline 141 & $5,000 \mu \mathrm{g}$ subcutaneously & $7.5 \times 10^{8}$ & $4 / 18$ & 22.2 & 6.9 & 0.01 \\
\hline 142 & $\begin{array}{l}\text { simultaneous with vac- } \\
\text { cine inoc. }\end{array}$ & $7.5 \times 10^{5}$ & $7 / 20$ & 35.0 & 10.6 & 0.01 \\
\hline 143 & As above then $5,000 \mu \mathrm{g}$ & $7.5 \times 10^{3}$ & $2 / 20$ & 10.0 & 12.6 & 0.01 \\
\hline 144 & $\begin{array}{l}\text { subcutaneously daily } \\
\text { for } 5 \text { days }\end{array}$ & $7.5 \times 10^{5}$ & $3 / 20$ & 15.0 & 19.3 & 0.01 \\
\hline 145 & $1,500 \mu \mathrm{g}$ intravenously & $7.5 \times 10^{2}$ & $3 / 19$ & 15.7 & 9.3 & 0.01 \\
\hline 146 & $\begin{array}{l}\text { simultaneous and daily } \\
\text { for } 5 \text { days after vaccine } \\
\text { inoc. }\end{array}$ & $7.5 \times 10^{5}$ & $5 / 20$ & 25.0 & 15.2 & 0.01 \\
\hline 147 & $5,000 \mu \mathrm{g}$ subcutaneously 1 & $7.5 \times 10^{3}$ & $6 / 17$ & 35.3 & 3.13 & $0.05-0.10$ \\
\hline 148 & week after vaccine inoc. & $7.5 \times 10^{5}$ & $8 / 9$ & 42.1 & 7.8 & 0.01 \\
\hline 149 & $5,000 \mu \mathrm{g}$ subcutaneously & $7.5 \times 10^{3}$ & 6/17 & 35.3 & 3.13 & $0.05-0.10$ \\
\hline 150 & $\begin{array}{l}\text { daily during 2nd week } \\
\text { after vaccine inoc. }\end{array}$ & $7.5 \times 10^{5}$ & $3 / 16$ & 18.7 & 15.8 & 0.01 \\
\hline 151 & None & $7.5 \times 10^{3}$ & $4 / 18$ & 22.2 & 6.9 & 0.01 \\
\hline 152 & & $7.5 \times 10^{5}$ & $7 / 19$ & 36.8 & 9.7 & 0.01 \\
\hline 153 & None* & $7.5 \times 10^{3}$ & $14 / 20$ & $\mathbf{7 0 . 0}$ & - & - \\
\hline 154 & & $7.5 \times 10^{5}$ & $18 / 20$ & 90.0 & - & - \\
\hline
\end{tabular}

* Groups 153 and 154 received no vaccine. All others received $10^{10}$ viable streptomycin-dependent cells before streptomycin administration.

Four weeks elapsed between vaccine administration and challenge, and 4 weeks elapsed between challenge and sacrifice.

TABLE 4

Response of guinea pigs immunized with living streptomycin-dependent mutant

\begin{tabular}{|c|c|c|c|c|c|c|c|c|}
\hline \multirow{2}{*}{ G2008 } & \multirow{2}{*}{ VACCINE ADYINISTRATION } & \multirow{2}{*}{ CBALLENGX } & \multicolumn{2}{|c|}{ ImsT } & \multicolumn{2}{|c|}{ CONTROL } & \multirow{2}{*}{$\mathrm{CHI}^{2}$} & \multirow{2}{*}{$\mathbf{P}$} \\
\hline & & & $\begin{array}{c}\text { Infected/ } \\
\text { total }\end{array}$ & Per cent & $\begin{array}{l}\text { Infected/ } \\
\text { total }\end{array}$ & Per cent & & \\
\hline $\mathbf{A}$ & 3 inoculations: $1.7 \times 10^{10}, 4.7$ & 59 & $6 / 15$ & 40 & $8 / 9$ & 89 & 3.7 & $0.05-0.10$ \\
\hline B & $\times 10^{\circ}, 3.3 \times 10^{\circ}, \mathrm{two}$ weeks & 590 & $15 / 15$ & 100 & $10 / 10$ & 100 & - & - \\
\hline C & apart & 5,900 & $8 / 8$ & 100 & $10 / 10$ & 100 & - & - \\
\hline D & 2 inoculations: $1.7 \times 10^{10}, 4.7$ & 190 & $6 / 13$ & 46 & $6 / 10$ & 60 & 0.066 & $0.70-0.80$ \\
\hline $\mathbf{E}$ & $\times 10^{\circ}$, two weeks apart & 1,900 & $9 / 14$ & 64 & $10 / 10$ & 100 & 2.6 & $0.10-0.20$ \\
\hline $\mathbf{F}$ & & 19,000 & $14 / 14$ & 100 & $6 / 6$ & 100 & - & - \\
\hline G & 1 inoculation: $1.7 \times 10^{10}$ & 96 & $2 / 12$ & 17 & $8 / 10$ & 80 & 6.4 & $0.02-0.01$ \\
\hline $\mathbf{H}$ & & 960 & $11 / 14$ & 78 & $9 / 9$ & 100 & 0.73 & $0.30-0.50$ \\
\hline
\end{tabular}

Vaccine and challenge doses were administered subcutaneously in $1 \mathrm{ml}$ volumes.

All challenges were administered 3 weeks after the last vaccine inoculation, and all animals were sacrificed 4 weeks after challenge. 
which would make one optimistic over the chances of any but the third approach at the moment for goat, sheep, or even man, an organism was sought, the in vivo phases of which would not induce excessive pathologic changes and which after a period of viability in vivo would be eliminated; thus, the organism would be classed as relatively avirulent. The second aspect of the approach, tactical as it were, was the hypothesis that a streptomycin-dependent strain of $B$. melitensis might possess such I roperties with the further advantage that the in vivo growth of the organism be controlled by administration and subsequent withdrawal of the drug.

Experimentally the mutant has proven to be sound if judged by the findings in mice, whereas it has shown little success in the immunization of guinea pigs. Furthermore, administration of an antibiotic to the host did not affect the results in the mouse.

The effectiveness of the vaccine strain in mice has not been attributed conclusively to multiplication of the strain in vivo although the alternate possibility that the organisms merely persisted for the number of weeks indicated is more difficult to accept biologically. If the antibiotic is not available to the mutant in vivo, and the results of Magoffin and Spink (1951) amply indicate that it is not available to the intracellularly located Brucella, the organisms are by-passing in vivo the drug if multiplication is occurring. On the other hand, the very large numbers of cells required for immunization speak against effective multiplication and in favor of persistence in which case the data on in vivo administration of the drug are further clarified.

The ease with which mice were immunized when compared with guinea pigs emphasizes again the problem of using only the latter species of laboratory animal in assessing the immunogenic capabilities of brucella vaccines for larger animals and man. Mice are generally much more susceptible to immunization against Brucella species than guinea pigs. Data on the native antigens (Elberg et al., 1951), acetone killed Brucella cells (Smart, 1949), and now on the mutant strain attest to this. The guinea pig is extremely susceptible to Brucella infection and can be infected by very small numbers of organisms administered via a variety of routes. And it has been accepted by most investigators that if an animal as susceptible as the guinea pig can be protected by a vaccine, more resistant animals will also experience the protection. Since species do differ in their ability to be immunized by different preparations as illustrated by findings of Baker et al. (1951) in studies on Pasteurella pestis and by Jawetz and Meyer (1943) on the same organism, the use of only one species of laboratory animal to screen possible immunogenic agents in Brucella infections may have hindered the uncovering of effective vaccines.

The guinea pig is extremely variable in its response to immunization, and often experiments cannot be replicated. Elberg et al. (1951) could find little correlation between the variables studied in their immunizing procedures with the native antigen and the extent of protection resulting in the guinea pig although the results as a whole indicated a protective effect by the antigen. Other workers have noted this same phenomenon. Lisbonne et al. (1938) speak of their method of immunization "misfiring" on occasion, and McEwen and Roberts (1936) state that "although in the majority of experiments clear-cut results were obtained, this was not always the case. Why in a few instances vaccinated groups of animals showed little or no more resistance than the control animals is still obscure." These facts point to a great genetic variability in the guinea pig in regard to its response to immunization.

Administration of the streptomyoin-dependent mutant is a method of presenting the animal with the living organism containing its complement of antigens unaltered by any special method of extraction, killing, etc. Irrespective of the occurrence of in vivo multiplication it is possible to administer safely massive doses of the organism to mice and guinea pigs. Thus, it is possible to influence the results by varying the initial dose of vaccine.

Results of active immunization studies on the goat and monkey will be presented in a subsequent paper of this series.

\section{ACKNOWLEDGMENT}

The technical assistance of Miss Patricia Schneider and Mr. Leslie Page is gratefully acknowledged.

\section{SUMMARY}

A living streptomycin-dependent mutant of Brucella melitensis was able to confer significant protection on the mouse against experimental infection. Administration of the antibiotic to the 
immunized mice failed to enhance the immunity so induced. The streptomycin-dependent mutant protected guinea pigs only against small doses of virulent organisms.

\section{REFERENCES}

Baker, E. E., Sommer, H., Foster, L. E., Meyer, E., ANd Meyer, K. F. 1951 Studies on immunization against plague. I. The isolation and characterization of the soluble antigen of Pasteurella pestis. J. Immunol., 68, 131-145.'

Elberg, S. 1952 Unpublished observations.

Elberg, S., ANd Herzberg, M. 1953 Immunity in brucellosis. Federation Proc., 12, 441.

Elberg, S., Herzberg, M., Schneider, P., Silverman, S., ANd Meyer, K. F. 1951 Studies on the immunization of guinea pigs and mice to brucella infection by means of "native antigen". J. Immunol., 67, 1-13.

Herzberg, M., ANd Elberg, S. 1953 Immunization against Brucella infection. I. Isolation and characterization of a streptomycin-dependent mutant. J. Bact., 66, 585-599.

Jawetz, E., AND Meyer, K. F. 1943 Avirulent strains of Pasteurella pestis. J. Infectious Diseases, 73, 124-143.
Lisbonne, M., Roman, G., and Renoux, G. 1938 Vaccination "vraie" du cobaye contre $B$. melitensis. Comm. du lab. de Microbiol. de la faculté de medicine de Montpellier et du centre de recheres sur la fievre ondulante de l'Institute Bouisson-Bertrand, Montpellier.

Live, I. 1949 Effect of adjuvants upon the immunizing quality of ether killed Brucella abortus. Am. J. Vet. Research, 10, 347-350.

McEwen, A. D., And Roberts, R. S. 1936 Bovine contagious abortion. The use of guinea pigs in immunization studies. J. Comp. Pathol. Therap., 49, 97-117.

Magoffin, R. L., And Spink, W. W. 1951 The protection of intracellular brucella against streptomycin alone and in combination with other antibiotics. J. Lab. Clin. Med., 37, 924-930.

Olitzki, A. L., And Szenberg, E. 1953 Toxicity, infectivity and antigenicity of a streptomycin dependent mutant of Brucella abortus (strain 19). Proc. Soc. Exptl. Biol. Med., 82, 539-541.

SmaRT, K. L. 1949 Immunity studies in Brucella infection of the mouse. Thesis. University of California, Berkeley. 